\title{
パーソナルモビリティの安全・安心な自律回避法
}

\section{Safe and secure autonomous collision avoidance strategy of personal mobility}

\author{
$\bigcirc$ 城代 志野（東大） \\ 正 小竹 元基（東大） 正 鎌田 実（東大）
}

\author{
Yukino JODAI, The University of Tokyo, jodai@sl.t.u-tokyo.ac.jp \\ Kohei OKABE, The University of Tokyo \\ Motoki SHINO, The University of Tokyo \\ Minoru KAMATA, The University of Tokyo
}

\begin{abstract}
Personal Mobility (PM) is required to avoid pedestrians considering the impact on both rider and pedestrians in order to move autonomously on sidewalks. The objective of this study is to propose and evaluate a new strategy of safe and secure autonomous collision avoidance based on risk evaluation. Subjective evaluations of autonomous pedestrian avoidance show that a pedestrian, walking in front of the PM, can mentally influence on a rider. This result leads the strategy to calculate risk more highly when pedestrians are in front of the PM. The safety of the locomotion based on this proposed strategy is evaluated by theoretical simulation. The validity of the proposed strategy is verified by subjective evaluations through the experiment, using a powered wheelchair simulator.
\end{abstract}

Key Words: Personal Mobility, Autonomous robot, Avoiding behavior, Personal Space, Risk evaluation

\section{1. 序論}

\section{1 背最と目的}

近年, パーソナルモビリティ $(\mathrm{PM})$ と総称される一人乗り 移動体の開発が行われている.PM は快適な移動を実見する次 世代移動体として期待されており, その機能や形状は利用目 的に忘じてさまざまである. 本研究では, 運枟が困難な高䟻 者や身体障がい者の自立・自律移動を支援する機器としての PM の利用に着目する. そこで, 電動車いすの機能に加え, 自 律移動機能をPM に搭載することを提案し，利用者の移動の 負担を軽減することを目指す。自律移動機能は，走行環境を 認識・理解し外部からの支援を受けずに移動する機能[1]とする。

歩行空間において安全な自律移動を行うためには，移動中 に変化する環境を認識・理解することにより, 進路変更や停 止等の移動方策を選択し, 安全確保を行わなくてはならない. しかし, 安全性の過剩な追求は, 移動体の本質的な機能であ る移動を妨げる可能性があり, 搭乗者と歩行者が安心して移 動できる程度に衝突のリスクを許容する必要がある. したが って, 本研究は, 安全と安心を両立する自律移動の実現を目 指した衝突回避法を, リスク評価の観点から提案する.

\section{2 本研究の位而つけ}

人と共存して自律移動するロボットに関して,人のすれ違い 行動時の軌跡を多量のビデオデータから算出し, その行動特 性に基づき人とすれ違うロボットを開発した研究 ${ }^{[2]}$ がある.こ の研究にて, 対面してすれ違う場合の人の均的な行動軌跡 が定量的に示されているが，これらの行動特性を自律移動口 ボットに適用した際の心理的効果は明らかにされていない.

確率的に予测される人閥の行動に基づく回避計画の研究 ${ }^{[3]}$ では，格子状に分割されたロボットの移動領域の “危険度” を，障害物との衝突確率と自車の運動エネルギーを用いて算 出することが提案されている。“危険度”を用いることにより， 障害物と衝突することなく目的地に到達できることがシミュ レーションから示されているが, 実環境における有効性は検 証されていない.さらに, 上記の研究においては, いずれも, 搭乗者の存在を考慮していない問題点がある.

本研究では, PM の移動が人に及ぼす心理的作用を把握した 上で, 回避法を提案する. また, 回避法に基づく移動を人の 主観で評価することにより，実環境における人と親和性の高 い自律移動の実現を目指す。

\section{2. 心理的作用の调查实験}

PM の搭乗者と歩行者が，PM の自律移動から受ける影響を 調査するため，実機を用いた被験者実験を行う．PMの搭乗者 と歩行者に心理的影響を及ぼす要因となり得る PM の移動の 状態量を影響要素と定義し, 影響要素を抽出することを, 実 験の目的とする.

\section{1 英臥方法}

影響要素の候補として,

(1) PM の速度

(2) PM と歩行者の回避距離

(3) PM と歩行者の寸れ違い距離

を仮定し，それぞれが PM の搭乗者と歩行者に及ぼす影響を 調査する.ここで, 回避距離は, 回避行動開始時の PM と歩 行者の距離を, 寸れ違い距離は, 最接近洔の PM と歩行者の 距離を表す。

心理的作用の計測に関して，心拍の生体指標を用いる手法 ${ }^{[4]}$ が提案されている. 本研究もこれを参考にするが, 生体指標 と心理的作用との直接的な関係を示すことが困難であるため, 本実験では，聞き取り調査による主観詊価を主に述べる.

実験は図 1 に示す自律移動機能を有する電動車いすを用い, 十分広い半屋外に片側をコーンで区切った通路を実験環境と して実施する. 実験条件は，実験環境において，

実験 A：対面して停止する歩行者のいる場合

実験 B：対面して歩行寸る歩行者のいる場合

の 2 条件とする. 各実験条件下で実験機は, 速度をパラメー タとして自律走行する. 各試行終了後に, 搭乗者と歩行者は, 互いに衝突しそうだと感じたかについて,

項目 1: 1分な余裕があった

項目 2: 余裕があった

項目 3: 普通だった

項目 4: もう少し余裕を持つべきだった

項H 5: 衝突するかと思った

の1から5の範囲で主観詊価を行う。ただし, 全く衝突しそ うでなかったため詊価できないという回答を 0 として扱う.

\section{3 实政結果}

下記の実験結果では，主観詊価のみに注目する。

【実踑 A】 PM は, 進行方向正面に停止する歩行者に向か って淔進し, 歩行者から一定の距離で停止した. なお，加速 


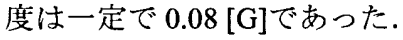

横軸に停止時におうる PM と歩行者の距離を, 縦軸に主観評 価をとったグラフを図 2 に示す。被験者保謢のため，本実験 では最接近距離を $1.7[\mathrm{~m}]$ に設定したところ, 項目 5 の評価を 得ることはなかった。 よって，本実験条件において，走行速 度に関わらず $1.7[\mathrm{~m}]$ 以上の距離を保って停止することで，人 に差し迫った衝突の危険を感じさせること無く移動できるこ とが分かった。

【実験 B】 PM と歩行者は対面して移動し，さまざまな回 避距離及びすれ違い距離ですれ違った. PM は直進, 又は進路 を変更する自律走行を行い，歩行者は自らの判断に基づき進 路変更による回避を行った.

回避距離とすれ違い距離を PM の車体に取り付けた測域セ ンサ（北陽電機 UTM 30-X）のデータから読み取り，それぞれ の主観評価との相関関係を調査した。 なお, PM の走行速度と して $2[\mathrm{~km} / \mathrm{h}]$ と $4[\mathrm{~km} / \mathrm{h}]$ を設定したが，回避距離やすれ違い距 離, 及び, 主観評価に特徵的な差異は見られなかったため, 全てのデータを分類せずに解析を行った.

結果, すれ違い距離に関しては，搭乗者（相関係数 -0.13）, 歩行者（相関係数 0.03）共に相関関係は確認できなかった.

一方, 回避距離に関しては, 歩行者の主観評価との相関係数 は-0.39となり，強い相関関倸は確認できなかったが，図 3 に 示すように，搭乗者の主観評価との相闒係数は-0.58 となり， 負の相関関係にあることが分かった。この結果から，搭乗者 は回避距離により衝突を評価していると考えられる。したが って, 回避距離が影響要素であり, 前方の歩行者に対して距 離を長く保って回避することが，搭采者の安心感の向上に有 効である可能性がある.

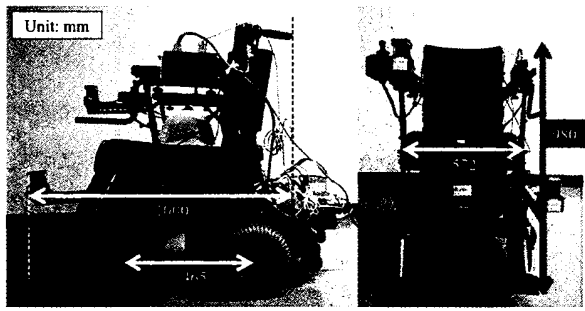

Fig. 1 Powered wheelchair used in the experiment

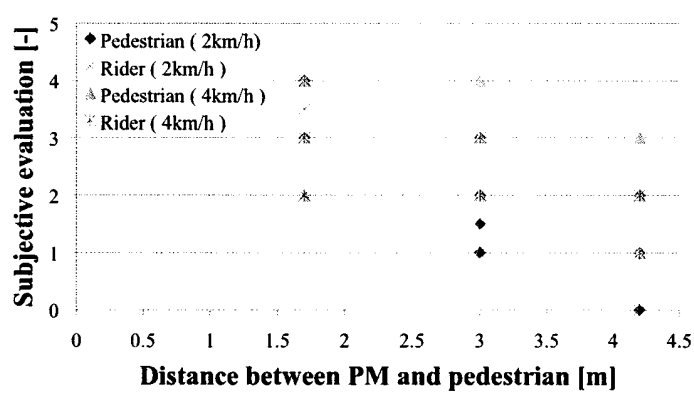

Fig. 2 Subjective evaluations of potential collision in experiment A

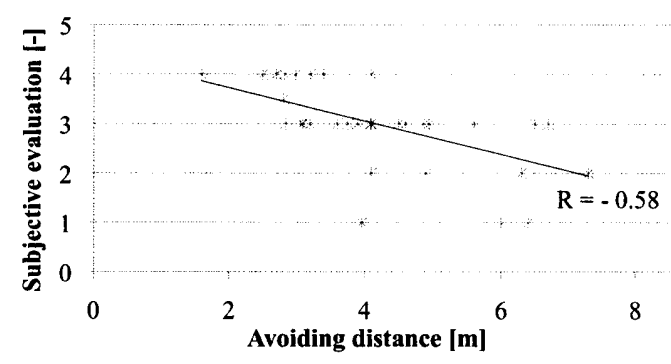

Fig. 3 Subjective evaluation of potential collision in experiment B

\section{3. 自律回避方策の決定}

移動噮境の情報から人と衝突するリスクを評価し，回避方 策を選択するアルゴリズムを提案する．本研究では，環境の 情報として歩行者の存在位置と瞬時速度ベクトルが, PMに取 り付けた测城センサから相対的に得られると仮定する。また, PM が人を乗せた状態で移動する際，とり得る移動方策は，搭 乗者の受容する方策, 及び, 車両性能により実現可能な方策 に限定されると仮定する.

\section{1 リスクの概念の弯入}

人と共存する機械の安全性評価の際，負の結果をもたらす 事象の生起確率と生起時の被害の大きさの組み合わせとして 定義されるリスクの概念が用いられる. 歩行空間を移動する PM は，衝突のリスク評価を行い，歩行者との衝突を防ぐと同 時に衝突洔の被害を抑える必要があると考えられる.よって, 本研究では, 各移動方策を選択した際の歩行者に衝突するリ スクを定量化した，リスク值を算出する.

\section{2 征突距離の定戥}

ある移動方策を選択した場合に歩行者と衝突する確率の定 量指標として, 衝突距離 $P$ を用いる. 衝突距離 $P$ は, 図 4 に 示すように, 歩行者の $\mathrm{PM}$ に対する相対座標を $\left(x_{0}, y_{0}\right)$, 歩行者 の PM に対する相対速度ベクトル上の半直線と座標軸の交点 を $\left(P_{x}, 0\right),\left(0, P_{y}\right)$ として, 次式により表される傎である.

$$
P= \begin{cases}P_{x \mid} & \left(\sqrt{x_{0}{ }^{2}+\left(y_{0}-P_{x}\right)^{2}}<\sqrt{\left(x_{0}-P_{y}\right)^{2}+y_{0}{ }^{2}}\right) \\ \frac{1}{\alpha}\left|P_{y}\right| & \left(\sqrt{x_{0}{ }^{2}+\left(y_{0}-P_{x}\right)^{2}} \geq \sqrt{\left(x_{0}-P_{y}\right)^{2}+y_{0}{ }^{2}}\right)\end{cases}
$$

ここで， $\alpha$ は，前方で衝突する可能性のある歩行者のリスク を高く算出するための係数である. 衝突距離 $P$ の值が大きい 移動方策を選択することで, 衝突を回避することができる.

\section{3 被害指数の定部}

歩行者の PMに対する相対速度 $\left(v_{x}, v_{v}\right)^{\mathrm{T}}$ の大きさを, 衝突時 の被害の大きさの指標として考え, 被害指数 $D$ を式(2)により 算出する．被害指数 $D$ は 0 から 1 の範囲で，被害が大きいほ ど 0 に近くなる値である.

$$
D=\frac{1}{1+\left(v_{x}^{2}+v_{y}^{2}\right)}
$$

\section{4 リスク位の定㭏}

衝突距離 $P$ と被害指数 $D$ の積をリスクの指標として, 式(3) から $N$ 人の歩行者存在下における移動方策のリスク值 $R$ を算 出する．リスク值は大きいほど危険であることを表す值であ る.

\section{5 移䣦方策の決定}

$$
R=\sum_{i=1}^{N} \frac{100}{1+P_{i} D_{i}}
$$

リスク俻の小さい移動方策を選択し, 歩行者との衝突のリス クが小さい移動を行うため, 図 5 に示すアルゴリズムを提案 する. 歩行者を検知すると，まず，図 4 に示す衝突領域と， 歩行者との関係に基づく衝突判定を行う.PM の占有領域を近 似する山の半径を $r[\mathrm{~m}]$, 人の占有領域を近似する山の直径を $d[\mathrm{~m}]$ とすると, 衝突領域は, $\mathrm{PM}$ を原点とする相対座標系 $x y$ において，原点を中心として半径 $r+d[\mathrm{~m}]$ の円内の領域と， 原点から $y$ 軸正方向沿って長さ $L[\mathrm{~m}]$ の直線である.

不要な回避行動を防ぐため, 回避の必要性に心じて 3 段階に 分類した衝突モードを定義する，衝突判定の結果，衝突モー ドが川忙とし得られる. 衝突モードの分類を下記に示す. 衝突モード 1: 衝突領域内に歩行者が存在する場合 衝突モード 2: 衝突モード 1 に該当せず，かつ, 衝突領域と 
歩行者の PM に対する相対速度べクトル上の半直線との交 点が存在する場合

衝突モード 0: 衝突モード 1 にも衝突モード 2 にも該当しな い場合

次に, 優先回避対象を決定する. 優先回避対象の決定は, 複 数の回避対象が存在する場合に, 最も優先的に回避する対象 を選定するプロセスであり, 洔閒的に差し迫った衝突を優先 回避対象とすると良いと考えた。 なお，衝突までの時間は， 歩行者が衝突領域に進入するまでの時間として算出する.

最後に, 優先回避対象のみに対して算出したリスク佔が減少 する方策を方策候補としてリスト化する，そして，方策候補 のなかから，リスク值が最も低くなる方策を選択する．PM の 移動中は，常にこのアルゴリズムに基づく移動方策の選択が 行われる.

\section{1 安全性の评俩}

\section{4. 回避法の妥当性検证}

\subsection{1 理境設定}

回避法の姿全性を詊価するため, シミュレーションによる解 析を行う. シミュレーション空閒は, 幅 $2.5[\mathrm{~m}]$, 全長 $10.2[\mathrm{~m}]$ の通路とする. また, PM の占有領域を近似する山の半径 $r$ を $0.5[\mathrm{~m}]$, 歩行者の占有領域を近似する以の直径 $d$ を $0.5[\mathrm{~m}]$ と仮定し, 衝突領域を設定した。影響調査実験の結果を踏ま え，パラメータは $\alpha=1.7 ， L=2.0$ に設定した。ささらに，PMの

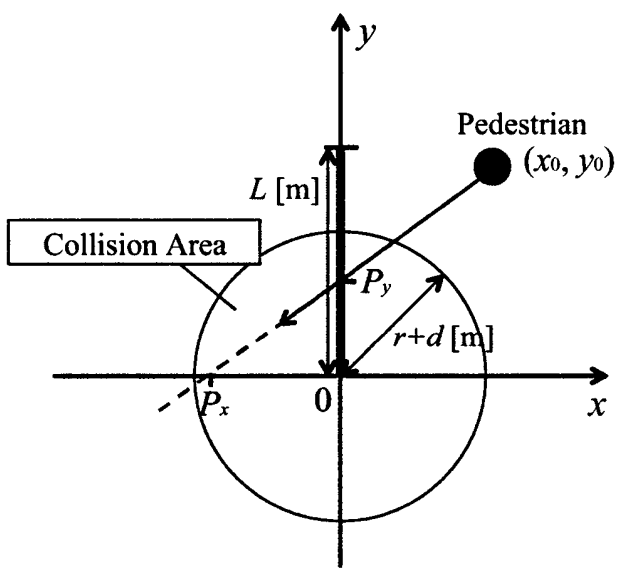

Fig. 4 Collision area and collision distance

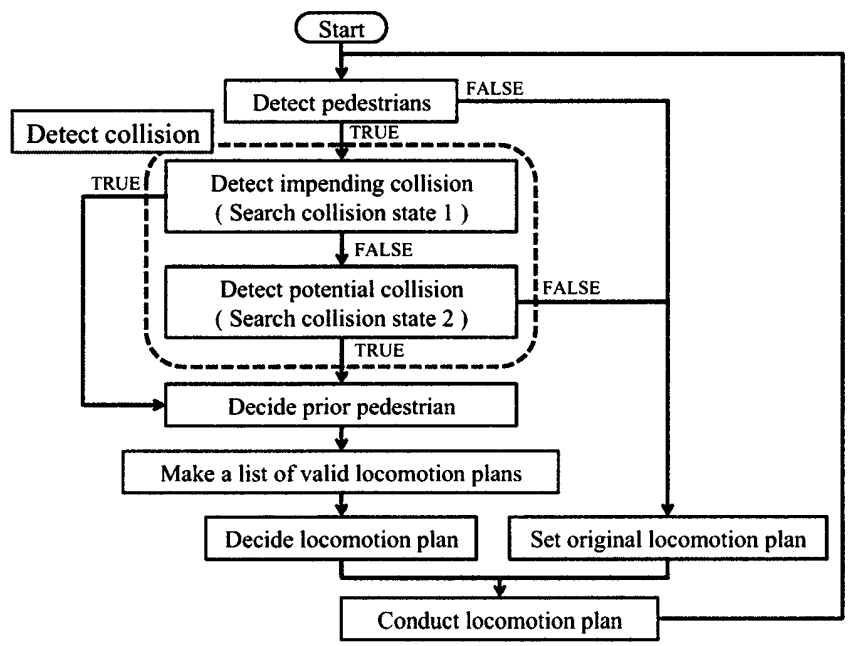

Fig. 5 Algorithm of deciding locomotion plan
移動方策は, 左右 $45[\mathrm{deg}]$ 以下の範囲にお污る進路変更と設定 速度以下での直進とする.

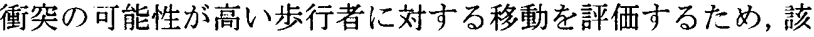
当する歩行者を, PM を原点とする相対座標系 $x y$ に招ける存 在位置と相対速度べクトルに基づく定性的分類により抽出し た. 衝突の可能性が高い歩行者の存在位置と相対速度べクト ルを図 6 に実線で示す.シミュレーション空閒は $y$ 軸につい て対称であるため, 表 1 に示す計 9 条件についてシミュレー ションを行った。 また，シミュレーションにおいては，歩行 者は同じ速度べクトルを維持して移動すると仮定した。

\subsection{2 シミュレーション結果}

速度 $4.0[\mathrm{~km} / \mathrm{h}]$ で加速を許容しない場合と, $6.0[\mathrm{~km} / \mathrm{h}]$ までの 加速を許容する場合を実験条件として設定した結果, PM の前 方から接近する歩行者, すなわち, F の位置に存在する歩行者 に対しては, 衝突せずに移動できることが確認できた。また， PM の側方と後方から接近する歩行者, 寸なわち, R と B の位 置に存在する歩行者との衝突事象が両方の条件で確認できた。 衝突せずに移動できた条件 F-6において，PM は通路端に奇 り歩行者を回避した. 条件 F-6におけるリスク值の推移を図 7 に示す．すれ違うまでのリスク值は高く算出されているが，

寸れ違った後のリスク值は低いことが分かる。

条件 B-1 では, 後方から接近する歩行者に対するリスクを低 減させるため, PM は初め, 歩行者と同方向の速度ベクトルを 持って通路の端に寄る行動をとった. PM が通路の端に到達し たため同方向の速度べクトルを持つことが不可能になると直 進し, その結果, 衝突した. 条件 B-1 の歩行者に関して, 歩 行者と PM の距離を横軸に, リスク佔を縌軸にとったグラフ を図 8 に示す.図より, $6[\mathrm{~km} / \mathrm{h}]$ までの加速を許可することで, 同距㜠にある歩行者に対するリスク做が減じていることが分 かる. また, 接近距離の最小值も大きくなっており, 高い速 度まで川速を許容することで, 衝突のリスクを抑えることが できる可能性が示された。しかし，接近距離は衝突の目安と なる $0.75[\mathrm{~m}]$ を依然として下回っていることから, 衝突を防ぐ ことはできていない.これは, 歩行者の速度を, PM の $6[\mathrm{~km} / \mathrm{h}]$ を上回る $10[\mathrm{~km} / \mathrm{h}]$ に設定したためと考えられる。このような 高速での背後からの追突は, 主に歩行者の前方不確認による 不㕕全行動として実際に存在し得る。安全性向上のため, 警 報器等による注意喚起を行うことが有効である可能性があり， さらなる検討が必要である.

\section{2 主镜研価による妥当性検征实的}

提案した安全・安心な回避法により，PMの搭乗者の安心感 が向上することを確認するため，電動車いすシミュレータを 用いた被験者実験を行う。

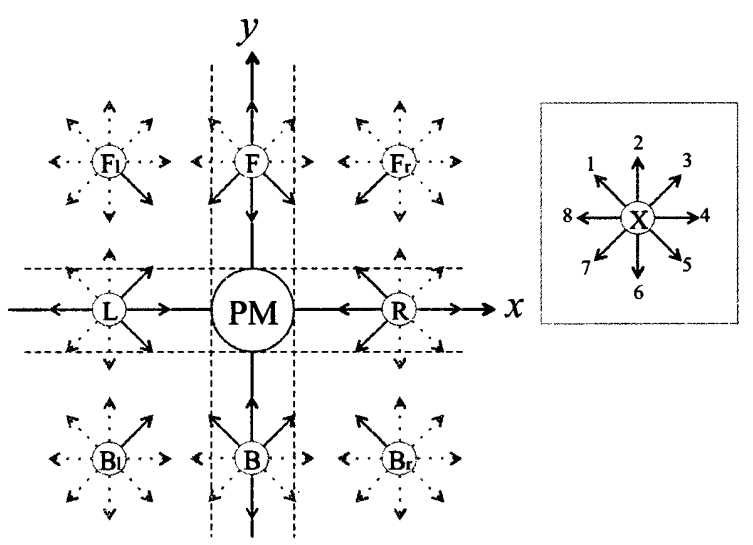

Fig. 6 Positions and vectors of pedestrians 
Table 1 Conditions in simulation

\begin{tabular}{l|r|r}
\hline Condition & Velocity $[\mathrm{km} / \mathrm{h}]$ & Angle to "8" [deg] \\
\hline F-6 & 0 & 90 \\
\hline F-7 & 8.2 & 80 \\
\hline Fr-7 & 2 & 60 \\
\hline B-1 & 10 & -70 \\
\hline B-2 & 10 & -90 \\
\hline Br-1 & 10 & -70 \\
\hline R-1 & 6.3 & -45 \\
\hline R-7 & 2.8 & 45 \\
\hline R-8 & 4.5 & 0 \\
\hline
\end{tabular}

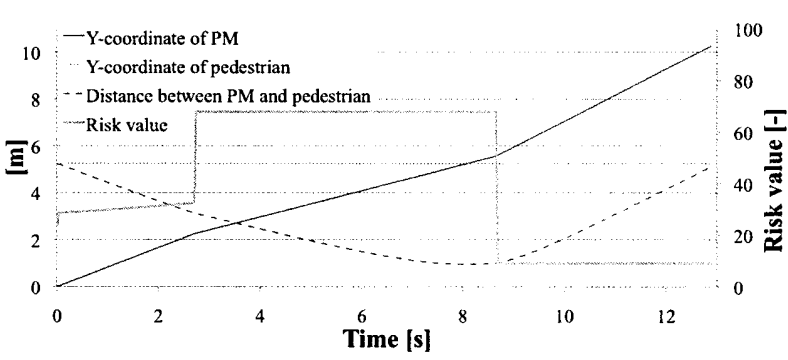

Fig. 7 Risk value in condition F-6

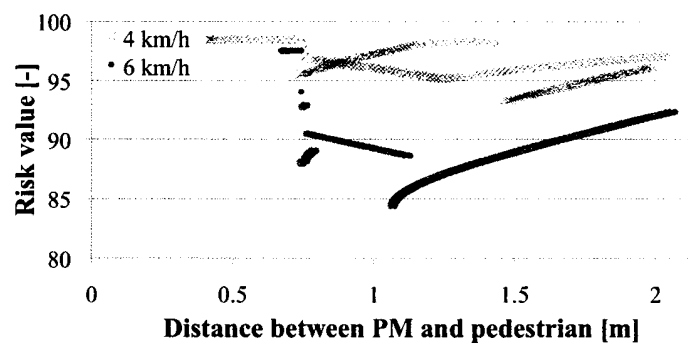

Fig. 8 Difference in risk value relative to speed in B-1

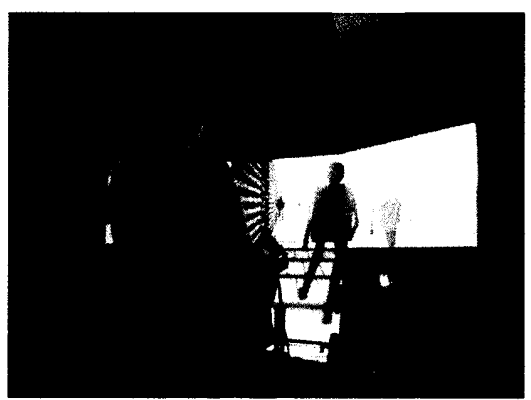

Fig. 9 Powered wheelchair simulator

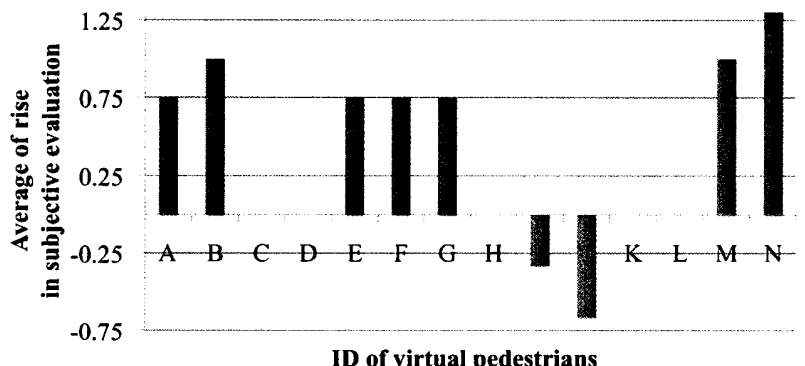

Fig. 10 Disparity in subjective evaluations by considering security

\subsection{1 实験方法}

実験は,シミュレータ上に, 線と壁により区切った幅 $2.5[\mathrm{~m}]$ の通路を作成し，PMの進行方向前方の通路上に仮想的な歩行 者 14 体（ID: A〜N）をランダムに配置することにより実際の 歩行空間を模擬して実施する. 使用したシミュレータの概観 を図 9 に示す. 20 代男性 4 名の被験者は, $\alpha=1.0, L=0.0$ の場 合の移動（安全な移動）之, $\alpha=1.7, L=2.0$ の場合の移動（安 全・安心な移動）を行うシミュレータに搭乗し，シミュレー タ上に存在する各歩行者それぞれに対して第 2 章の実験で用 いた指標を用い，1 から5の範囲で主観評洒を行う。

\subsection{2 实酫結果}

安全な移動と安全・安心な移動における歩行者 14 体に対す る被験者の評価值の差の平均を図 10 に示す. 結果, 歩行者 I と歩行者 $\mathrm{J}$ に対する評価が低下したが, 他の歩行者に対しての 詊価は維持，又は，向上することが確認できた.

歩行者 Iに対する評価が墨化した被験者は 1 名であり，他の 被験者の評価に変化は無かった. 歩行者 $\mathrm{I}$ は, 搭乗者の前を横 切るように歩行する歩行者であり, 安全・安心な移動におい ては, 歩行者 I が横切る閒, 前方の接近距離を長くするため PM は停止していた。 その結果, 歩行者が前方に存在する時間 が長くなったため, 評価が悪化した可能性がある.

また, 歩行者 $\mathbf{J}$ は, 安全・安心な移動において, 安全な移動 と比較して前方への接近距離が約 $0.5[\mathrm{~m}]$ 短くなった.これは, 㓩方から, 歩行者 $\mathrm{J} よ り$ 高速で対面して接近してくる歩行者 $\mathrm{K}$ に対して，大きく回避行動をとったためである。この結果， 被験者の歩行者 $\mathrm{J}$ に対する評価は悪化したと考えられる.

歩行者 C, D, H, K, L に対しては，全員の被験者が，安全 な移動において, 項目 3 より良い評洒をしており, 安全・安 心な移動においても評洒は低下しなかった。

他の歩行者に関しては, 安全・安心な移動において, 安全な 移動に比べて PM と歩行者の, PM の進行方向前方における接 近距離が伸び, その結果, 岀心感が向上する傾向が確認でき た. したがって, 提案した回避法により, 安全・安心な自律 回避を歩行空間において行うことができる可能性がある。

\section{5. 結論}

本研究では, PMの歩行空閒における衝突のリスク評価に基 づく白律回避法を, 心理的作用を調查する被験者実験を踏ま えて提案した. そして, 提案した回避法の論理的安全性と, パラメータ設定による人に与える安心感への影響を検証した。 結果, 提案した回避法の適切なパラメータ設定により，人に ちえる安心感を向上させながら, 歩行空閒において自律回避 を行うことができる可能性が示された.

今後は, 提案した自律回避法に基づく移動を行う PM を, 実 機を用いて試作し, 実際の自律移動における PM の搭乗者の 心理的評価に加え, PMに対する歩行者の心理的評価について も考察する方針である.

\section{文 献}

[1] 日本上業標潐調查会, “移動ロボットー用語,” JIS B 0186, 2003.

[2] 依田光正, 塩田泰仁, “人開とすれ違い行動を行う移動ロボットの 研究, ”日本ロボット学会誌, vol. 17,pp. 202-209, 1999.

[3] 田所諭, 林真樹, 真部靖弘, 中見至宏, 高森年, “人間と共存協 調するロボットのための回避行動の生成（第 2 報, 移動ロボット の移動障害物回避),”日本機械学会論文集 (C 編), 63 巻 606 号, pp. 499-505, 1997.

[4] 栗谷川幸代, 景山一郎, “機械操作時にお括る心負担推定に用い る心拍変動モデルの構築,”月本機械学会論文集 (C 編), 66 巻 643 号, pp. 140-146, 2000. 